\title{
Role of the Finnish forest industry in mitigating global change: energy use and greenhouse gas emissions towards 2035
}

\author{
Satu Lipiäinen ${ }^{1}$ (D) Esa Vakkilainen ${ }^{1}$ \\ Received: 7 April 2020 / Accepted: 14 February 2021 / Published online: 19 March 2021 \\ (C) The Author(s) 2021
}

\begin{abstract}
The objective of this paper is to analyse role of forest industry in meeting energy and climate targets that aim to mitigating global change. Finland as an important forest industry country with the ambitious target of becoming carbon neutral by 2035 is selected to a target county. This study aims to present a plausible assessment of the future of the Finnish forest industry until 2035 based on literature and a scenario building approach. The focus is on energy use and fossil carbon dioxide $\left(\mathrm{CO}_{2}\right)$ emissions. The results suggest that electricity consumption will decrease, whereas electricity production will increase, which indicates that forest industry can provide more renewable electricity to the grid. Heat consumption may even increase as a result from building new biorefineries, but those mills can most probably meet their heat demand by combusting biofuels. Changes in forest industry's direct fossil $\mathrm{CO}_{2}$ emissions can reduce Finnish fossil $\mathrm{CO}_{2}$ emissions 2-4\% in comparison to 2018. Biofuels production is likely to rise, but the extent remains to be seen. It is concluded that the Finnish forest industry can contribute significantly to meeting national climate policy targets, and forest industry in general can play a role in mitigating global change. Additionally, it was found that development of the Finnish forest industry will probably be limited by the requirement for sustainable wood harvesting, which may also be a problem for other forest industry countries.
\end{abstract}

Keywords Forest industry $\cdot \mathrm{CO}_{2}$ emissions $\cdot$ Energy use $\cdot$ Climate change mitigation $\cdot$ Climate policy $\cdot$ Scenario building

Satu Lipiäinen satu.lipiainen@lut.fi 


\section{Introduction}

Climate change is one of the greatest global challenges of the twenty-first century (Solnørdal and Foss 2018), and mitigation of climate change-related threats requires a substantial reduction in global greenhouse gas (GHG) emissions. World leaders and international organizations are leading efforts to promote a change towards more sustainable development, and the European Union (EU), for example, has set demanding energy and climate targets for 2030. Key EU objectives are a $40 \%$ reduction in GHG emissions compared to 1990, a $32 \%$ share for renewable energy and a 32.5\% energy efficiency improvement (EEI) (European Commission n.d.). In line with EU policy, the Finnish government has included in its programme the strategic objective of becoming a completely carbon neutral society by 2035 (Ministry of the Environment 2020). Additionally, Finland aims to increase the share of renewable energy in final energy consumption to $50 \%$ and to replace $40 \%$ of fossil transportation fuels with renewable alternatives (Ministry of Economic Affairs and Employment 2017).

Industry is a major energy user and an emitter of fossil $\mathrm{CO}_{2}$. Energy efficiency improvement and decarbonising different industrial sectors are crucial for meeting energy and climate targets in global, EU and national levels (European Commission 2019). Forest industry, especially pulp and paper industry, is an energy-intensive sector. Pulp and paper industry is the world's fourth largest industrial energy user and accounts for $2 \%$ of industrial direct $\mathrm{CO}_{2}$ emissions (Trudeau et al. 2011). Finnish forest industry has been promoting reduction of $\mathrm{CO}_{2}$ emissions, and majority (85\%) of fuels used in Finnish forest industry are bio-based (Finnish Forest Industries 2018). However, it still accounts for about $5 \%$ of total fossil $\mathrm{CO}_{2}$ emissions in Finland (Statistics Finland 2019b; Energy Authority). If forest industry aims to reach carbon neutrality, as Finnish forest industry does, fossil fuels must be replaced with bio-based alternatives. Moreover, forest industry can contribute to emission reduction by production of bio-based materials, fuels and renewable energy. In Finland, forest industry is the major player in the industrial sector, which covered 47\% (148 TWh) of final energy consumption in 2018 (Statistic Finland 2019a). At 22\%, the share of total electricity consumption is also high (Finnish Energy 2020). As the forest industry is both the main producer and consumer of bioenergy (Finnish Forest Industry 2018), it can play an important role in meeting political targets regarding the use of renewable energy.

Forecasting the future of forest industry is challenging because several drivers for change, such as climate change, population growth, demographic changes, development of information technology (IT), structural changes of global economy, growing energy demand and increasing scarcity of biodiversity and resources, are affecting the business environment. Demands for different products are changing, and continuing demands to reduce energy use and emissions require existing mills to improve energy efficiency. Among the drivers for change, availability of wood resources affects the development of forest industry in Finland. In 2018, 78.2 $\mathrm{Mm}^{3}$ of roundwood was harvested for industrial and energy use (Natural Resource Institute Finland (Luke) 2018), whereas the estimated sustainable annual harvesting rate is only $80.5 \mathrm{Mm}^{3}$ (Natural Resource Institute Finland (Luke) 2020). Moreover, forests absorb $\mathrm{CO}_{2}$ and act as carbon sinks (Siljander and Ekholm 2018). There have been a lot of discussions whether forests must be protected instead of used by industrial and energy sector. This study assumes that Finnish forest sector can continue harvesting as long as forests are sustainably managed and annual harvesting rate does not surpass the growth rate.

Several studies have considered the future of the forest industry, of which most focus primarily on production development (Buongiorno et al. 1998; Bolkesjo et al. 
2003; Buongiorno 1996; Johnston 2016) or innovative technologies and products (Möllerstein et al. 2006; Kong et al. 2016; Hamaguchi et al. 2012; Hämäläinen et al. 2011). A small number of studies considering future directions of the forest industry have taken energy and climate issues into account. Johnsson et al. (2019), Fleiter et al. (2012) and Szabó et al. (2009) evaluated energy saving and greenhouse gas mitigation potential. Nyström and Cornland (2003) reviewed the potential role of the Swedish forest industry in reducing $\mathrm{CO}_{2}$ emissions, and Ericsson et al. (2011) studied the role of climate and energy policies in the prospective development of the Swedish pulp and paper industry. The future of the Finnish forest industry has been the subject of some recent studies and reports (Pöyry 2016; Koljonen et al. 2019; Kivistö et al. 2013). However, the role of the Finnish forest industry in meeting EU and national energy and climate policy targets that aims to mitigate global change remains unclear.

Hurmekoski and Hetemäki (2013) evaluate several methods used for outlook studies in the forest sector. Each method has benefits and weaknesses, and typically method selection depends on the specific case studied. This study uses a scenario building approach because it enables several alternative futures to be reviewed and consequently gives a broad view of possible outcomes. None of the forecasts can describe the future perfectly, and the results should therefore be considered indicative. The review period of this study is moderate, under 20 years, and the reviewed area is limited to Finland. Therefore, detailed assumptions and some mill-by-mill analysis can be done.

The aim of this paper is to examine role of forest industry in mitigating global change. Finland is chosen as a target country as it has been a forerunner in the bioeconomy producing a large variation of bioproducts and having a renewable-based fuel mix and sustainably used forest resources (Finnish Forest Industry 2010). The main question is how energy use and fossil $\mathrm{CO}_{2}$ emissions in the Finnish forest industry will develop to 2035. Role of Finnish forest industry in reducing energy consumption, contributing to fossil $\mathrm{CO}_{2}$ emissions mitigation and producing renewable energy is evaluated.

This paper consists of five sections. After this introduction, section 2 presents used materials, describes the scenario building method and introduces assumptions and initial values. Section 3 shows the results of scenario building presenting how electricity and heat consumption, electricity production and $\mathrm{CO}_{2}$ emissions could develop to 2035 and considers how forest industry can contribute to mitigation of global change. Section 4 discusses about possible uncertainties and limitations, compares the study to previous ones and provides future research topics. Finally, section 5 presents the conclusions of the results.

\section{Methods and materials}

The method employed in this study uses a scenario building approach to evaluate development of energy use and fossil $\mathrm{CO}_{2}$ emissions in Finnish forest industry to 2035. Development of wood use is included as availability and use of wood resources are an important issue. Literature review is completed to find out what is the initial stage of Finnish forest industry and what kinds of trends are affecting it. Previous studies investigating future of Finnish forest industry and publications of forest industry companies are reviewed. Trends are used in scenario building. 


\subsection{Finnish forest industry: current situation and future}

Finnish forest industry is a major producer of pulp, paper and mechanical forest industry products (FAO 2019). In 2017, it produced 3.1 Mtons of mechanical pulp, 8.0 Mtons of chemical pulp, 5.4 Mtons of printing and writing papers, 3.6 Mtons of packaging materials, 1.2 Mtons of other papers, $1.4 \mathrm{Mm}^{3}$ of wood-based panels, $11.8 \mathrm{Mm}^{3}$ of sawnwood, 0.4 Mtons of solid biofuels and 0.2 Mtons of liquid biofuels. Total fuel use was $226 \mathrm{PJ}$ and fossil fuel use 35 PJ (Statistics Finland 2019a). Approximately 2.6 Mtons of fossil $\mathrm{CO}_{2}$ was emitted (Energy Authority 2019). Electricity consumption and production were $20 \mathrm{TWh}$ and $10 \mathrm{TWh}$, respectively (Finnish Forest Industries 2018). Historical development of Finnish forest industry is presented in Appendix Fig. 3.

Previous studies (e.g. Hänninen et al. 2013; Pöyry 2016; Koljonen et al. 2019) have investigated development of Finnish forest industry. The Finnish forest industry is going through a structural change. Several printing and writing paper and mechanical pulp mills were closed, and new packaging paper and chemical pulp mills were built in 2010s (Kähkönen et al. 2019). The change is continuing, and many forest industry projects are in the design phase. Major projects include three large pulp mills and several mills that would produce advanced biofuels from wood. The total capacity of the planned pulp mills is high, approximately 2.6 million tons per year (Metsä Fibre n.d.-b; Kaicell Fibers 2020; Boreal Bioref 2019). Fulfilment of all the project plans would increase chemical pulp production capacity by almost $30 \%$. Thus, if all these projects are realized, it is very likely that significant existing capacity will be closed.

It is to be expected that new bioproducts, such as biofuels, nanocellulose, textile fibres, intelligent packages, hemicellulose and lignin, will become increasingly important in the forest industry product mix (Hurmekoski et al. 2018). In recent years, Finland has become a forerunner in the field of integrated biotechnology in forest industry mills. For example, the Sunila pulp mill produces 50,000 t/a of lignin, the Kaukas biorefinery produces 130,000 t/a of biodiesel from tall oil, the Enocell mill produces dissolving pulp for textiles, and the large Äänekoski pulp mill based biorefinery produces several bioproducts from its side streams (Stora Enso n.d.-a, b; Metsä Fibre n.d.-a; UPM Biofuels 2020). Moreover, a mill in Kajaani uses sawmill residues as a raw material for transportation fuel (St1 2019).

In addition to production changes, energy use and consequently $\mathrm{CO}_{2}$ emissions are likely to change. The motivation of mills to implement energy savings and emission reductions can be affected by political means such as $\mathrm{CO}_{2}$ taxes and emissions trading. In Finland, the use of coal for energy production will be banned from May 2029 (Finnish Government 2019). Additionally, there has been a lot of debate about banning peat combustion. Use of peat will probably end during the 2030s due to high taxation (Wahlström et al. 2017). In addition to political means, technological development, especially biomass-based carbon capture and storage or utilization (BECCS, BECCU) technologies, may accelerate reductions in emissions in the future forest industry (Kuparinen et al. 2019).

\subsection{Choosing the scenarios, initial values and assumptions}

The purpose of scenarios is to analyse possible futures. In this study, building the scenarios starts with analysing the most crucial factors affecting the energy use and $\mathrm{CO}_{2}$ emissions. Sector's activity, structure and energy efficiency define sector's energy consumption (Stenqvist 2015), and therefore, those factors were identified as key variables. 
Based on literature, two main development paths for development of production were identified. The first path follows current trends: decreasing grades (mechanical pulp, printing and writing papers, wood-based panels) continue their decrease, whereas currently increasing grades (chemical pulp, packaging and other papers, sawnwood, bioproducts) will increase also in the future. The second one assumes that new biorefinery projects will be realized, and therefore, pulp production is strongly increasing as well as production of biofuels and new bioproducts.

As energy efficiency has an important impact on energy use, it is included in the scenarios. Energy efficiency improvement is impossible to predict accurately as several factors such as technology, operational modes, energy management and prevailing policies are affecting it. In this study, the uncertainty is managed using two different energy efficiency improvement rates. The two different development paths for production are combined with high and low energy efficiency improvement rates forming four scenarios. These scenarios assume that forest industry will be increasing. However, it is possible that factors such as tightening competition about raw materials or changes in global competitiveness may weaken Finnish forest industry. Therefore, scenario with decreasing production rates is created to complete palette of scenarios. These five scenarios describe effect of different development paths of production and energy efficiency on energy use of Finnish forest industry in many ways.

The state of forest industry in 2017 is used as a reference scenario. Development of forest industry's fossil $\mathrm{CO}_{2}$ emissions is not directly related to energy use because changes in energy use may not lead to a change in fossil fuels use but to change in use of biofuels or purchased energy. Thus, studying development of fossil $\mathrm{CO}_{2}$ emissions needs more assumptions. Those and other assumptions are introduced in the following sections. The assumptions and initial values are based on literature review and values presented in previous studies when applicable.

\subsection{Production rates and wood consumption}

Changes in production volume and structure have a major contribution to development of energy use. Grade changes have an important impact, because specific energy consumption varies between different grades. In this study, three possible development paths for production rates are established to be able to consider alternative futures (Table 1). Production rates in scenarios I-IV are own evaluations that are based on literature (e.g. Hänninen et al. 2013; Pöyry 2016; Koljonen et al. 2019; FAO 2019). Production rates for scenarios I and II follow current trends. No new pulp and paper mills are built in these scenarios, but renovations and capacity increases are carried out in existing mills. Scenarios III and IV take into account biorefinery projects that are currently in a design phase, which can be seen as a high growth rate of chemical pulp. Paper industry is doing better than in scenarios I and II as well as production of biofuels and new bioproducts. It is assumed that increasing competition about wood leads to decrease in production of wood-based panels and sawnwood. In scenario V, growth rates are chosen to predict decline in Finnish forest industry. Production of conventional forest industry products is decreasing, but production of biofuels and new bioproducts is slightly increasing. The model excludes replacement of old mills with new ones except in case of chemical pulp mills. In this study, chemical pulp capacity is restricted to 10 million tons per year due to wood availability and pulp demand issues. Building the new chemical pulp mills in scenarios III and IV leads to decrease in old capacity.

In addition to production changes, changes in roundwood consumption are estimated. Used specific wood consumption values for mechanical pulp, chemical pulp, sawnwood and wood- 
Table 1 Growth rates of forest industry products in Finland until 2035 in the different scenarios

\begin{tabular}{|c|c|c|c|c|}
\hline Grade & Unit & $\begin{array}{l}\text { Scenarios I \& II } \\
\text { Change }\end{array}$ & $\begin{array}{l}\text { Scenarios III \& IV } \\
\text { Change }\end{array}$ & $\begin{array}{l}\text { Scenario V } \\
\text { Change }\end{array}$ \\
\hline Mechanical pulp & $\% / \mathrm{a}$ & -1.7 & -2.0 & -2.5 \\
\hline Chemical pulp & $\% / \mathrm{a}$ & 0.5 & 1.2 & -0.5 \\
\hline Other papers & $\% / \mathrm{a}$ & 0.5 & 0.7 & -0.5 \\
\hline Packaging paper & $\% / \mathrm{a}$ & 0.3 & 0.5 & -0.5 \\
\hline Printing \& writing paper & $\% / \mathrm{a}$ & -2.0 & -1.5 & -3.0 \\
\hline Wood-based panels & $\% / \mathrm{a}$ & -0.2 & -0.5 & -2.0 \\
\hline Sawnwood & $\% / \mathrm{a}$ & 0.3 & -0.1 & -2.0 \\
\hline Biofuels (s) & $\% / \mathrm{a}$ & 1.0 & 3.0 & 0.5 \\
\hline Biofuels (l) & $\% / \mathrm{a}$ & 5.0 & 11.0 & 2.0 \\
\hline New bioproducts & 1000 tons & 100 & 400 & 50 \\
\hline
\end{tabular}

based panels are 1.10 tons $/$ ton, 2.17 tons $/$ ton, 1.15 tons $/ \mathrm{m}^{3}$ and 1.22 tons $/ \mathrm{m}^{3}$, respectively. It is assumed that other products do not use roundwood as raw material. Values are calculated using data provided by FAO (2019) and Natural Resource Institute Finland (Luke) (2019).

\subsection{Energy use}

According to Fracaro et al. (2012), average annual energy efficiency improvement (EEI) of the Finnish chemical forest industry between 1979 and 2009 was $0.39 \%$ per year. As the value is relatively low, it is used as lower energy efficiency improvement rate. The higher production rate is set to be twice as high than the lower rate, 0.78\%/a. In many cases, literature states higher EEI rates. For example, Odyssee-Mure (2015) reports that industrial energy efficiency improved $0.9 \%$ /a between 2007 and 2013. Therefore, both selected values are moderate to avoid too optimistic results. The energy efficiency improvement term in the equation applies only to old mills. Energy efficiency improvement of new mills is included using specific energy consumption values (Table 2). Development of energy consumption is calculated using Eq. (1).

Table 2 Specific energy consumption values of old and new mills. Evaluated using data from Nature Resource Institute Finland (Luke) (2019), Kähkönen et al. (2019) and Pöyry (2016)

\begin{tabular}{|c|c|c|c|c|c|}
\hline \multirow[b]{2}{*}{ Product } & \multirow[b]{2}{*}{ Unit } & \multicolumn{2}{|c|}{ SEC, electricity } & \multicolumn{2}{|l|}{ SEC, heat } \\
\hline & & Old units & New units & Old units & New units \\
\hline Mechanical pulp & $\mathrm{MWh} / \mathrm{t}$ & 1.92 & 1.60 & 0.17 & -0.19 \\
\hline Chemical pulp & $\mathrm{MWh} / \mathrm{t}$ & 0.67 & 0.53 & 3.19 & 2.83 \\
\hline Printing \& writing paper & $\mathrm{MWh} / \mathrm{t}$ & 0.82 & 0.61 & 1.37 & 1.21 \\
\hline Paperboard & $\mathrm{MWh} / \mathrm{t}$ & 0.57 & 0.52 & 1.48 & 1.26 \\
\hline Other paper & $\mathrm{MWh} / \mathrm{t}$ & 1.25 & 0.85 & 2.41 & 1.81 \\
\hline Sawnwood & $\mathrm{MWh} / \mathrm{m}^{3}$ & 0.08 & 0.08 & 0.31 & 0.31 \\
\hline Wood-based panels & $\mathrm{MWh} / \mathrm{m}^{3}$ & 0.16 & 0.16 & 0.61 & 0.60 \\
\hline Biofuels (s) & $\mathrm{MWh} / \mathrm{t}$ & - & 0.25 & - & 0.72 \\
\hline Biofuels (1) & $\mathrm{MWh} / \mathrm{t}$ & - & 1.33 & - & 1.47 \\
\hline New bioproducts & $\mathrm{MWh} / \mathrm{t}$ & - & 1.00 & - & 1.00 \\
\hline
\end{tabular}




$$
E=E_{0}+\overbrace{\left(1-\frac{\Delta P_{x}}{P_{t o t, x}}\right)}^{\text {Share of old capacity }} \overbrace{\left[E_{0}(1-\varepsilon)^{\left(v_{x}-v_{0}\right)}-E_{0}\right]}^{\text {Energy efficiency improvement }}+\overbrace{\sum_{i=1}^{n}\left(w_{n, i} P_{n, i}-w_{o, i} P_{o, i}\right)}^{\text {Structure and volume change }}
$$

where $E$ is energy consumption of the Finnish forest industry in a certain year [GWh], $E_{0}$ is initial energy consumption in a reference year [GWh], $\Delta P_{x}$ is new capacity in a certain year [tons], $P_{\text {tot, } x}$ is total capacity in a certain year [tons], $\varepsilon$ is energy efficiency improvement [\%/a], $v_{x}$ is the year reviewed, $v_{0}$ is a reference year, $w_{n, i}$ is specific energy consumption of new capacity of a certain grade [GWh/ton], $w_{o, i}$ is specific energy consumption of old capacity of a certain grade [GWh/ton], $P_{n, i}$ is new capacity of a certain grade [tons], and $P_{o, i}$ is closed capacity of a certain grade [tons].

Specific energy consumption (SEC) values are chosen separately to old and new mills as it is assumed that new mills are more energy efficient than older ones. The values are based on previous studies. No specific old energy consumption values are presented for production of biofuels or new bioproducts as it is assumed that mills producing those products will not be closed during studied period.

Development of electricity production in the Finnish forest industry is estimated using the logic presented in Eq. (1). It is assumed that the lion's share of the electricity is generated by market chemical pulp mills and integrates. Reference mills for new and old units are chosen based on Finnish pulp and paper mill electricity production data (Table 3). All forest industry mills are different with unique characteristics, and therefore, evaluating future electricity production using reference mills is challenging. No data about annual energy production efficiency improvement rates was available. However, the technology will most probably develop, and therefore, energy production efficiency improvement rates are set to $0.10 \% / \mathrm{a}$ and $0.20 \% / \mathrm{a}$.

\subsection{Greenhouse gas emissions}

This study considers only $\mathrm{CO}_{2}$ emissions from use of fossil fuels in forest industry mills. Emissions of energy companies that locate in the same site and produce energy for the mills are excluded, because typically their major task is to produce energy for external use, and therefore, it is challenging to allocate emissions to forest industry and energy sector. Those emissions that are produced when energy company produces energy for forest industry mill are classified as indirect emissions. The amount of $\mathrm{CO}_{2}$ emitted is related to the energy consumption and fuel mix.

$$
\mathrm{CO}_{2}=\sum_{i=1}^{n} P_{i} \cdot S E C_{i} \cdot F \cdot I
$$

Table 3 Specific electricity production values of old and new capacity. Evaluations based on data from previous study (Kivistö et al. 2013)

Electricity production (MWh/ton)

\begin{tabular}{llll}
\hline $\begin{array}{l}\text { Type of } \\
\text { capacity }\end{array}$ & $\begin{array}{l}\text { Market chemical pulp } \\
\text { mill }\end{array}$ & $\begin{array}{l}\text { Integrated mechanical pulp and } \\
\text { paper mill }\end{array}$ & $\begin{array}{l}\text { Integrated chemical pulp and } \\
\text { paper mill }\end{array}$ \\
\hline New & 1.38 & 0.58 & 1.27 \\
Old & 0.84 & 0.28 & 0.92 \\
\hline
\end{tabular}


where $\mathrm{CO}_{2}$ is total emissions of the forest industry [ $\left.\mathrm{tCO}_{2} / \mathrm{a}\right], P_{i}$ is annual production of a certain product [tons/a], $S E C_{i}$ is specific energy consumption of a certain product [GJ/ton], $F$ is share of fossil fuels [GJ/GJ], and $I$ is $\mathrm{CO}_{2}$ intensity of the fossil fuels mix $\left[\mathrm{CO}_{2} / \mathrm{GJ}\right]$. This study considers only changes in amount of used fossil fuels as it is assumed that forest industry companies aim to reduce use of fossil fuels and $\mathrm{CO}_{2}$ emissions significantly (e.g. UPM 2020).

For studying the future, the major sources of fossil $\mathrm{CO}_{2}$ emissions were identified. The main fossil $\mathrm{CO}_{2}$ emitter in chemical pulp industry is the lime kiln, which typically uses natural gas or oil as fuel, followed by fossil fuels use in mill boilers during start-ups, stoppages and other exceptional situations (Kuparinen et al. 2019). Peat and coal are used in biomass boilers, for increasing steam production and reaching full capacity when the biomass fuel is wet. Some oil and gas are used to balance steam generation and to ensure steam supply during stoppages in auxiliary boilers. Several mills use natural gas in drying devices. The forest industry does not generate all the energy it needs, and it therefore causes also indirect $\mathrm{CO}_{2}$ emissions, which are not included in this study.

Contributions of different fossil fuel sources to total emissions are evaluated to enable studying the future $\mathrm{CO}_{2}$ emissions. The following assumptions have been made: an average lime kiln emits $120 \mathrm{kgCO}_{2}$ /ton of pulp; average biomass boiler and recovery boiler start-up and shut-down emit $20 \mathrm{kgCO}_{2} /$ ton of pulp and $10 \mathrm{kgCO}_{2} /$ ton of pulp, respectively; every pulp mill has a recovery boiler; and $75 \%$ of the mills have a biomass boiler. Assumptions for $\mathrm{CO}_{2}$ emissions are adopted from Kuparinen et al. (2019). Calculations in this study do not consider the impact of carbon capture technologies. Those technologies may have an important role in the future, but previous studies (e.g. Teir et al. 2011) state that carbon capture will not be feasible in Finnish forest industry before 2030 because of lack of financial incentives. Therefore, it is assumed that CCS will not reach a significant role during studied period.

The starting point for calculations is based on fuels used in the Finnish forest industry in 2017 and their emission intensities (Table 4). With the assumptions above, it can be calculated that use of oil and natural gas in lime kilns supports fuels of recovery and biomass boilers, and incineration of peat and coal accounts for approximately $90 \%$ of Finnish forest industry $\mathrm{CO}_{2}$ emissions. The rest is emitted by auxiliary fuel oil and natural gas fired boilers, infrared dryers in paper drying processes, as well as other minor sources.

Use of peat, coal and fossil fuels in lime kiln is the main variable in scenarios. Literature review showed that burning coal will be banned, and use of peat will probably end during 2030s due to high taxation. Therefore, it is assumed that coal is not combusted in Finnish forest industry after 2029. Scenarios II and IV assume that Finnish forest industry is willing to invest in clean technology, and consequently both peat combustion and use of fossil fuels in lime kilns will stop. In scenarios I and III, forest industry is assumed to be less innovative, 50\%

Table 4 Emissions intensity and use of fuels in the Finnish forest industry (Fleiter et al. 2012; Alakangas et al. 2016; Energy Authority; Finnish Forest Industries 2018)

\begin{tabular}{llr}
\hline Fuel & Emission intensity $\left(\mathrm{tCO}_{2} / \mathrm{GJ}\right)$ & Use in $2017(\mathrm{PJ} / \mathrm{a})$ \\
\hline Biofuels & 0 & 206.1 \\
Natural gas & 0.056 & 14.7 \\
Peat & 0.106 & 8.8 \\
Heavy fuel oil & 0.078 & 6.1 \\
Coal & 0.094 & 2.8 \\
Other & 0.046 & 3.0 \\
\hline
\end{tabular}


and $75 \%$ of lime kilns use biofuels, and $50 \%$ and $75 \%$ of peat combustion is replaced. In scenario $\mathrm{V}$, it is assumed that forest industry is not willing to invest in new lime kilns, and the share of bio-based fuels is $50 \%$. However, peat use is assumed to end because energy use probably decreases significantly as a result of declining production. There are no major changes in use of start-up and shut-down fuels as they are only a minor user of fossil fuels and they are relatively challenging to replace. Residual fossil fuels remain constant except in scenario IV.

\subsection{Scenarios}

Five scenarios are created based on own evaluations and data found from literature. The scenarios aim to estimate emissions and energy use of Finnish forest industry in 2035 considering changes in volume, structure, energy efficiency and fuel mix. Scenarios I-V and reference scenario are presented in Table 5. In addition to $\mathrm{CO}_{2}$ emission sources listed in the table, start-up and shut-down fuels are estimated to emit approximately $0.24 \mathrm{MtCO}_{2}$ per year. However, it is assumed that there will be no major changes in the use of those fuels within the next 15 years.

\section{Results}

In all the scenarios studied, the structure of the Finnish forest industry will change in the future (Fig. 1). The production volume change in the whole Finnish pulp and paper industry from 2018 to 2035 is $-6.3 \%$ in scenarios I and II, $0.3 \%$ in scenarios III and IV and $-20.4 \%$ in scenario V. Production volume changes in the mechanical forest industry in scenarios I and II, in scenarios III and IV and in scenario V are $4.3 \%,-2.4 \%$ and $-29.1 \%$, respectively. Even though changes in total volume are moderate, the structure changes significantly. Conventional bulk products such as printing and writing paper will likely make room for innovative highquality products. New bioproducts remain a minor forest industry product, but their production grows in every scenario. There is a lot of uncertainty in the production volume of biofuels and new bioproducts. New products should be profitable, and at the same time, they must meet sustainability criteria. Industrial scale changes occur slowly, and therefore, production of biofuels or new bioproducts may not meet the estimated production volumes.

Production changes estimated in this study will increase roundwood consumption in most of the scenarios (Table 6). In addition to forest industry's wood consumption, energy wood is harvested. If wood imports and energy wood harvesting remain at the 2018 level, scenarios I-IV will probably surpass the limit of sustainable harvesting. Achieving a balance between increasing demand for wood and limited wood resources is an issue that Finland must solve. Competition for raw material will lead to increasing prices, which will affect the competitiveness of Finnish mills.

Increasing wood use will lead to growth in the availability of wood residues that can be used in energy production or for raw material. However, demand for wood residues is likely to increase notably as biofuels production is growing and forest industry mills as well as other actors have already stated aim of replacing fossil fuels with bio-based alternatives due to factors such as increasing taxation of fossil fuels and desire to enhance corporate's image. Strategies of forest industry companies and policies regarding bioenergy and biofuels will play a key role when decisions are made whether wood residues are used as raw material or energy. 


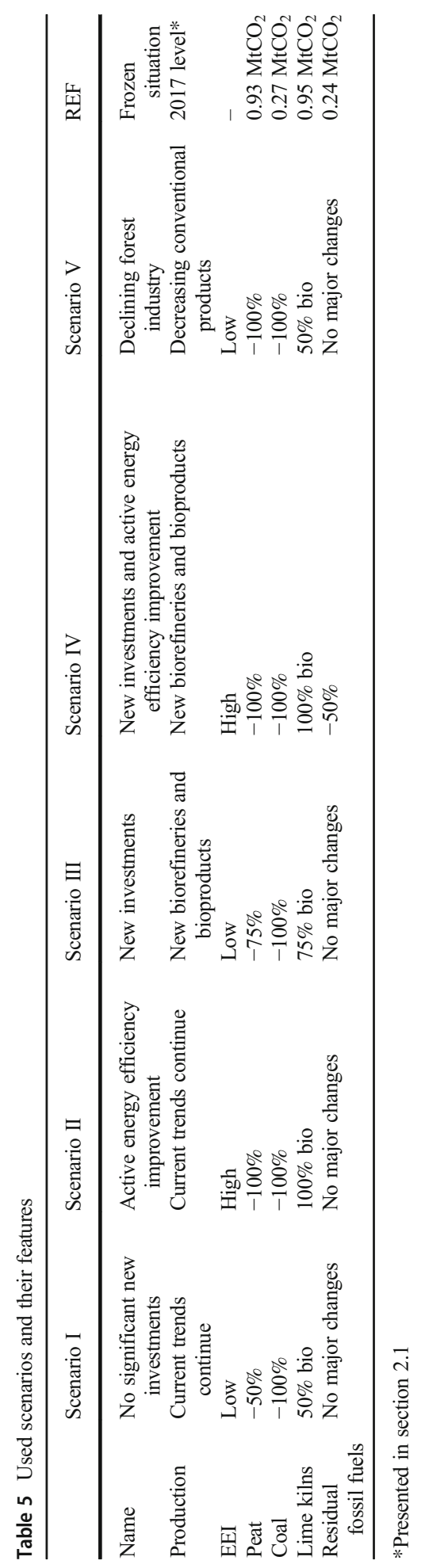




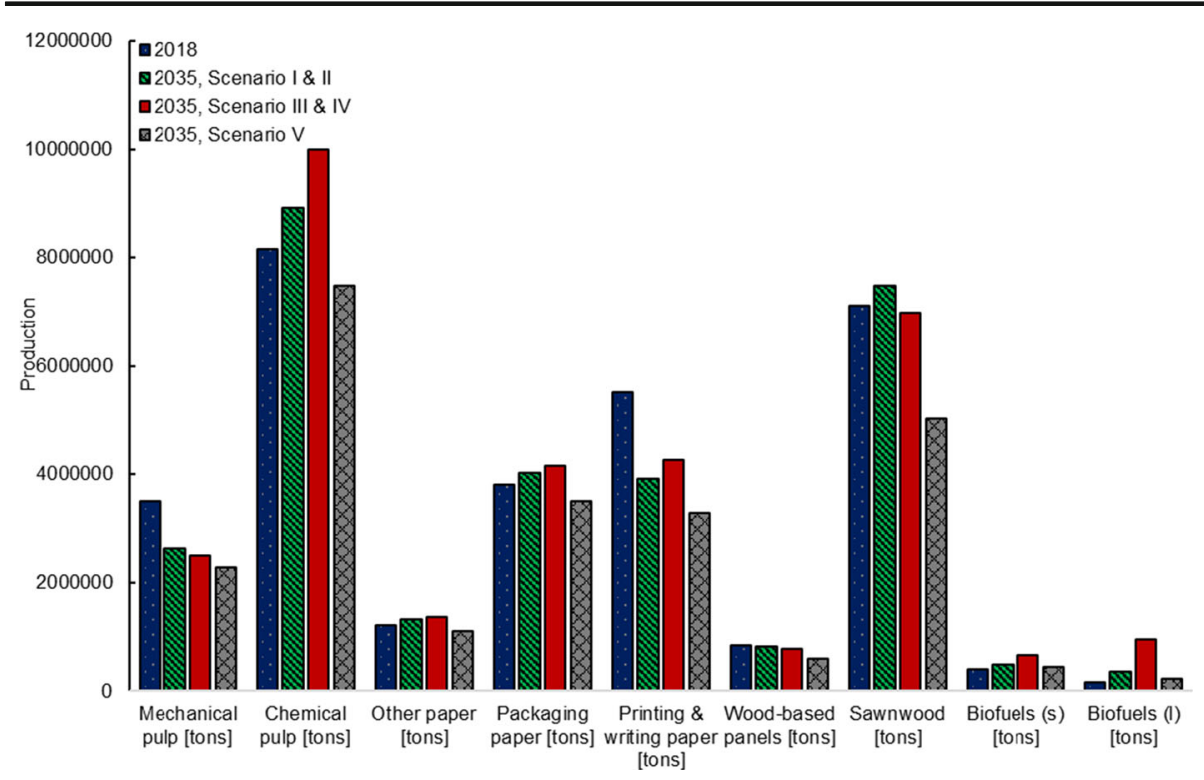

Fig. 1 Production changes in the Finnish forest industry from 2018 to 2035. Production of wood-based panels and sawnwood are converted to tons using density of 0.6 ton $/ \mathrm{m}^{3}$

A trend that applies to every scenario is declining electricity consumption (Fig. 2a). A decrease in electricity use can have several impacts. Firstly, combustion of fossil fuels may decrease which would reduce forest industry's $\mathrm{CO}_{2}$ emissions. Secondly, the electricity selfsufficiency rate of mills will likely increase. Decreased electricity demand may also lead to increase in the amount of bioelectricity available for sale on electricity markets. Thirdly, excess electricity can offer mills opportunities. For example, carbon capture and power-to-x technologies are more attractive if there is available renewable electricity in the mills. Heat demand in the different scenarios varies more than electricity demand (Fig. 2b). Scenario III predicts a $7.5 \%$ increase in heat use, whereas realization of scenario $\mathrm{V}$ will lead to a $22.4 \%$ decrease. Savings in final energy use will probably lead to reduction of fossil fuels and/or purchased energy. In such a case, the Finnish forest industry of the future will be more self-sufficient in terms of energy, and its fuel mix will be even more dominated by biofuels.

The results suggest that electricity production by the forest industry will increase in the future, with the exception of scenario V (Fig. 2c). Scenarios III and IV show that the construction of large pulp mills will have an important role in increasing the amount of electricity produced. Electricity self-sufficiency of new pulp mills can be over $200 \%$, and consequently there may be excess electricity in the mills. Oversupply of electricity may have the same effects as a decrease in electricity consumption. However, changes in electricity

Table 6 Wood consumption and available wood residues in the Finnish forest industry

\begin{tabular}{lllll}
\hline Year & 2018 & 2035 & & \\
\cline { 3 - 5 } Scenario & Current & Scenarios I \& II & Scenarios III \& IV & Scenarios V \\
\hline Wood consumption $\left[\mathrm{Mm}^{3}\right]$ & 73.6 & 76.3 & 78.6 & 59.1 \\
Wood residues $\left[\mathrm{Mm}^{3}\right]$ & 23.8 & 25.6 & 27.8 & 20.8 \\
\hline
\end{tabular}



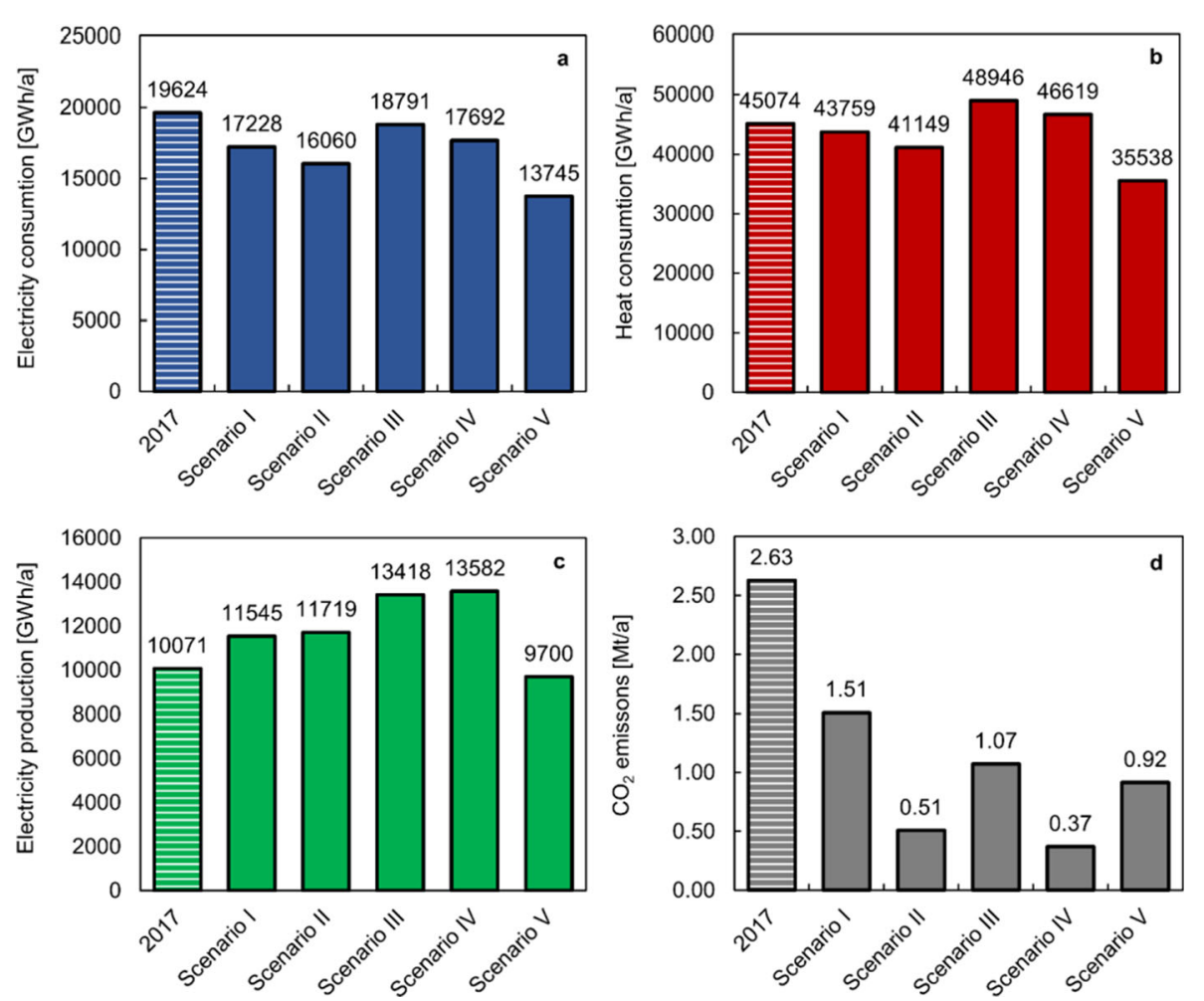

Fig. 2 Finnish forest industry development from 2017 to 2035: a electricity consumption, b heat consumption, c total energy consumption and $\mathbf{d} \mathrm{CO}_{2}$ emissions

production and the energy balance of Finnish mills are dependent on strategic choices, electricity prices, and competition for bio-based raw materials. A decrease in electricity consumption may lead to a notable drop in electricity production if there is no profitable use for the excess electricity. Also, decrease in heat consumption may reduce amount of electricity produced in combined heat and power plants.

Even though energy consumption may decrease and the availability of biomass from Finnish mills' own operations increases, which should help reach the target of a $\mathrm{CO}_{2}$ emissions-free forest industry, some technical barriers may cause challenges; for example, fossil fuels used as supporting fuels during start-ups and other exceptional situations may be difficult to replace. Many mills would be forced to make significant and expensive modifications to their energy systems if all fossil fuel were to be replaced with renewable alternatives, which may discourage especially companies that cannot meet additional renewable energy demand using internal wood residues and side streams.

The results of the scenario analysis suggest that the forest industry's $\mathrm{CO}_{2}$ emissions will decrease by $43 \%$ (scenario I) to $86 \%$ (scenario IV) by 2035, in comparison to 2017 (Fig. 2d). Replacing fossil fuels in lime kilns with bio-based alternatives and ending incineration of peat and coal will make a major contribution to $\mathrm{CO}_{2}$ emissions reduction. Savings in electricity and heat consumption will facilitate reduction of emissions that originate from energy production. In scenarios III and IV, energy consumption rises due to increasing production, and therefore, 
emissions mitigation is more challenging; however, the adoption of bio-based technologies may enable significant reductions.

Even though energy consumption reductions and availability of own biomass in mills ease reaching emission-free forest industry, total elimination of fossil $\mathrm{CO}_{2}$ emissions will need significant additional actions. Emerging technologies provide tools for moving forward on the path towards carbon neutrality, but the attractiveness of these technologies depends, among other factors, on costs and policies. Moreover, a decrease in overall energy consumption may not lead to a reduction in fossil fuels use but to a reduction in purchased energy, and a significant increase in electricity production might make reducing fossil fuels use even more challenging.

On the other hand, such a change would result in a significantly larger decrease in $\mathrm{CO}_{2}$ emissions. It should be noted that the use of carbon capture technologies was excluded from the scenarios. Such technology has high $\mathrm{CO}_{2}$ reduction potential, but its widespread adoption by 2035 is uncertain. Adoption of bioenergy with carbon capture and storage technologies (BECCS) can provide opportunity to transform pulp and paper industry carbon neutral or even negative emitter (Kuparinen et al. 2019). As future forest industry in Finland emits relatively low amounts of fossil $\mathrm{CO}_{2}$ emissions, BECCS could enable reaching the carbon neutrality. Moreover, printing and writing paper production capacity and mechanical pulp production will probably lead to the closure of mills with the lowest competitiveness. In many cases, these mills have lower energy efficiency than average. Furthermore, integrated mechanical pulp and paper mills and stand-alone paper mills are typically dependent on fossil fuels. Therefore, such closures can facilitate a reduction in total $\mathrm{CO}_{2}$ emissions.

Changes in energy consumption of the Finnish forest industry until 2035 result mainly from production volume and mix changes (Table 7). Structural changes affect the ratio of heat and electricity needed. Especially changes in production mix of pulp affect the energy use. Chemical pulp is a heat-intensive product, whereas mechanical pulping requires a lot of

Table 7 Energy saving resulting from production changes and energy efficiency improvement from 2017 to 2035

\begin{tabular}{|c|c|c|c|c|c|c|c|c|}
\hline Scenario & $\begin{array}{l}\text { Mechanical } \\
\text { pulp }\end{array}$ & $\begin{array}{l}\text { Chemical } \\
\text { pulp }\end{array}$ & $\begin{array}{l}\text { Packaging } \\
\& \text { other } \\
\text { papers }\end{array}$ & $\begin{array}{l}\text { Printing } \\
\& \text { writing } \\
\text { paper }\end{array}$ & $\begin{array}{l}\text { Mechanical } \\
\text { forest } \\
\text { industry }\end{array}$ & $\begin{array}{l}\text { Biofuels \& } \\
\text { other new } \\
\text { bioproducts }\end{array}$ & $\begin{array}{l}\text { Energy } \\
\text { efficiency }\end{array}$ & Total \\
\hline \multicolumn{9}{|c|}{ Heat $(2017=45,074 \mathrm{GWh})$} \\
\hline I & $-0.3 \%$ & $4.8 \%$ & $1.0 \%$ & $-4.9 \%$ & $0.4 \%$ & $1.0 \%$ & $-6.2 \%$ & $-4.2 \%$ \\
\hline II & $-0.3 \%$ & $4.8 \%$ & $1.0 \%$ & $-4.9 \%$ & $0.4 \%$ & $1.0 \%$ & $-12.0 \%$ & $-10.0 \%$ \\
\hline III & $-0.4 \%$ & $12.4 \%$ & $1.5 \%$ & $-3.8 \%$ & $-0.3 \%$ & $3.9 \%$ & $-5.8 \%$ & $7.5 \%$ \\
\hline IV & $-0.4 \%$ & $12.4 \%$ & $1.5 \%$ & $-3.8 \%$ & $-0.3 \%$ & $3.9 \%$ & $-11.3 \%$ & $2.1 \%$ \\
\hline $\mathrm{V}$ & $-0.5 \%$ & $-4.7 \%$ & $-1.4 \%$ & $-6.8 \%$ & $-2.9 \%$ & $0.4 \%$ & $-6.5 \%$ & $-22.4 \%$ \\
\hline \multicolumn{9}{|c|}{ Electricity $(2017=19,624 \mathrm{GWh})$} \\
\hline I & $-8.6 \%$ & $2.1 \%$ & $1.0 \%$ & $-6.7 \%$ & $0.2 \%$ & $2.0 \%$ & $-6.4 \%$ & $-16.3 \%$ \\
\hline II & $-8.6 \%$ & $2.1 \%$ & $1.0 \%$ & $-6.7 \%$ & $0.2 \%$ & $2.0 \%$ & $-12.3 \%$ & $-22.3 \%$ \\
\hline III & $-10.0 \%$ & $5.6 \%$ & $1.5 \%$ & $-5.2 \%$ & $-0.2 \%$ & $7.7 \%$ & $-6.0 \%$ & $-6.6 \%$ \\
\hline IV & $-10.0 \%$ & $5.6 \%$ & $1.5 \%$ & $-5.2 \%$ & $-0.2 \%$ & $7.7 \%$ & $-11.6 \%$ & $-12.2 \%$ \\
\hline $\mathrm{V}$ & $-12.0 \%$ & $-2.3 \%$ & $-1.5 \%$ & $-9.3 \%$ & $-1.6 \%$ & $0.7 \%$ & $-6.7 \%$ & $-32.8 \%$ \\
\hline \multicolumn{9}{|c|}{ Total energy $(2017=64,698 \mathrm{GWh})$} \\
\hline I & $-2.8 \%$ & $4.0 \%$ & $1.0 \%$ & $-5.4 \%$ & $0.3 \%$ & $1.3 \%$ & $-6.2 \%$ & $-7.9 \%$ \\
\hline II & $-2.8 \%$ & $4.0 \%$ & $1.0 \%$ & $-5.4 \%$ & $0.3 \%$ & $1.3 \%$ & $-12.1 \%$ & $-13.7 \%$ \\
\hline III & $-3.3 \%$ & $10.3 \%$ & $1.5 \%$ & $-4.2 \%$ & $-0.3 \%$ & $5.0 \%$ & $-5.9 \%$ & $3.3 \%$ \\
\hline IV & $-3.3 \%$ & $10.3 \%$ & $1.5 \%$ & $-4.2 \%$ & $-0.3 \%$ & $5.0 \%$ & $-11.3 \%$ & $-2.2 \%$ \\
\hline $\mathrm{V}$ & $-4.0 \%$ & $-4.0 \%$ & $-1.4 \%$ & $-7.6 \%$ & $-2.5 \%$ & $0.5 \%$ & $-6.6 \%$ & $-25.5 \%$ \\
\hline
\end{tabular}


electricity. Pulping is becoming more heat-intensive. The expected decrease in printing and writing paper production will leads to notable heat and electricity savings, whereas production of biofuels and new bioproducts may increase the energy use significantly. Energy efficiency improvement will make an important contribution to energy saving in every scenario.

The forest industry can play an important role in meeting Finland's climate and energy policy targets. The results suggest that final energy consumption in the forest industry will decrease. As bioenergy becomes even more predominant form of energy, the forest industry will probably incinerate fewer fossil fuels, which will lead to lower emissions. $\mathrm{CO}_{2}$ emissions in Fig. $2 \mathrm{~d}$ are equal to a 2.0-4.0\% decrease in Finland's total emissions. Moreover, the results suggest that while the forest industry's electricity consumption will decrease, electricity production may increase. Thus, mills may have excess electricity, which can be sold on electricity markets and increase the amount of renewable electricity used in the economy as a whole. The forest industry may also become an important producer of advanced biofuels, which will enable Finland to meet its targets regarding the share of renewables in transportation fuels. Additionally, new bioproducts may serve as substitutes for fossil-based materials such as plastics.

\section{Discussion}

Some megatrends are clearly discernible and already affect social, economic and industrial developments worldwide. The size of the impact of these developments is unknown, and only rough estimates can be made. Unexpected developments can appear suddenly and require forecasts to be updated. For example, changes in the global economy have profound effects on the Finnish forest industry, and the economic crisis of 2008-2009 caused several unit closures in Finland. Most future studies done before the crisis were unable to account for such a sudden and dramatic change in economic activity. Within the context of this study, possible political actions by EU in the energy and climate sector could change the Finnish forest industry dramatically, which may affect the validity of the scenarios developed. Moreover, the Finnish forest industry is in transition. Many conventional products have lost their overwhelmingly dominant position and new innovations and product groups are emerging. The forest industry's transformation towards a biorefineries concept with innovative products in addition to the core products of sawn goods, pulp and paper has been expected for a number of years. Currently, however, the Finnish forest industry is still predominantly focused on the production of conventional products with few new products being produced in commercial volumes. Pressure to produce more sustainable products and fuels may accelerate the transformation, but far-reaching change will probably still take time. At the moment, it is impossible to predict with certainty which of the new innovations will break through to become high volume products.

The results suggest that forest industry can contribute to climate change mitigation. Some previous studies (e.g. Lundmark et al. 2014) as well argue that forest sector can participate on $\mathrm{CO}_{2}$ reduction. This study focused on energy-related aspects, whereas many previous studies have concentrated as well on strengthening forests' carbon sinks and evaluating what is the role of substituting fossil-based materials with wood-based alternatives. Notably, Siljander and Ekholm (2018) claim that using forests as a carbon sink would be a more cost-effective way to reduce emissions than using them as a bioenergy source, but they also agree that wood-based products can be useful for mitigating climate change. Exact role of forests as a sink, energy 
source and raw material is unclear, and future studies probably will shed more light on this question.

This study is limited to investigate how production, energy use, energy production and direct fossil $\mathrm{CO}_{2}$ emissions could develop in the future. The main limitation is that the study does not estimate indirect changes, i.e. how much increasing renewable electricity production can decrease fossil $\mathrm{CO}_{2}$ emissions of the energy sector or what is the role of new biofuels and bioproducts in reducing fossil-based material use. Moreover, the impact of forest industry on forests as a carbon sinks is out of focus. The study is limited to Finland. However, forest industry is a globally important sector, and many studied trends apply also for other countries' forest industry. The findings can be used for those countries where applicable. In addition, as the forest industry currently produces $5 \%$ of Finnish fossil $\mathrm{CO}_{2}$ emissions, reaching national emissions reduction targets requires major reductions in other sectors. In Finland, energy sector, industry and traffic are the main emitters (Statistic Finland 2019a). Metal industry, chemical industry and pulp and paper industry are the major players in terms of $\mathrm{CO}_{2}$ emissions. To meet Finnish climate and energy targets, other sectors should be studied as well. Further studies are needed to cover these limitations.

\section{Conclusion}

This study investigated development of Finnish forest industry's energy use and fossil $\mathrm{CO}_{2}$ emissions to 2035 using five scenarios and assessed how possible changes would affect the attainment of climate and energy targets that aim to mitigate global change. Forest industry has the opportunity to promote low-carbon society and bioeconomy as it is a major user and producer of bioenergy, biofuels and bioproducts. Impact of bioproducts on reduction of national fossil $\mathrm{CO}_{2}$ emissions was out of the focus of this study. Forest industry is an energy-intensive sector, and when there are fossil fuels in fuel mix, a significant amount of fossil $\mathrm{CO}_{2}$ emissions can be emitted. Finnish forest industry has been a forerunner in decarbonizing the forest sector, but it still has potential to reduce fossil $\mathrm{CO}_{2}$ emissions notably. The reduction requires replacements of peat and coal in power boilers, and oil and natural gas in lime kilns with renewable alternatives. The scenario analysis results indicate that the drop in fossil $\mathrm{CO}_{2}$ emissions from changes in the forest industry could lead to a $2-4 \%$ reduction in Finland's total emissions compared to 2018. Possible carbon capture (BECCS) was not included in the scenarios due to current lack of incentives. The $\mathrm{CO}_{2}$ reduction potential may therefore be notably higher. If new biorefinery projects are realized, production of renewable electricity will probably increase notably. Energy efficiency improvement and changes in production mix decrease forest industry's electricity consumption, and consequently a larger share of produced electricity can be sold to the grid. The role of the Finnish forest industry in advanced biofuels supply is still unclear. The industry already produces some biofuels, and their production is likely to increase in the future, but the extent remains to be seen. The results suggest that wood resources are a limiting factor for Finnish forest industry. Four of the scenarios indicate that domestic roundwood consumption could approach or surpass the limit of sustainable harvesting especially if harvesting of energy wood remains at the 2018 level. Moreover, debate about forests protection creates uncertainties for forest industry. 


\section{Appendix. Trends in Finnish forest industry}
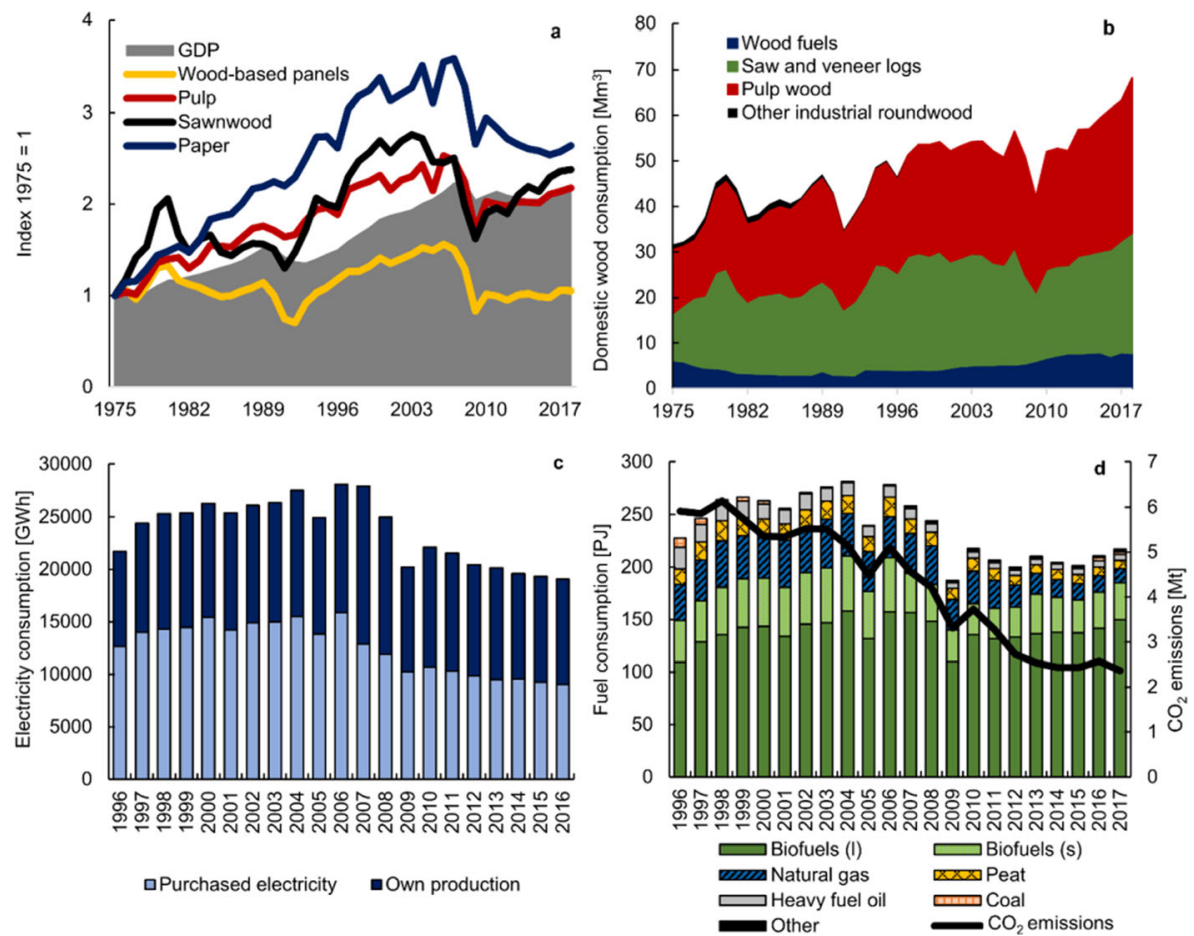

Fig. 3 Development of the Finnish forest sector: a Gross domestic product (GDP) and production rates, b domestic wood consumption, $\mathbf{c}$ electricity production and consumption and $\mathbf{d}$ fuel consumption and fossil $\mathrm{CO}_{2}$ emissions. Data from FAO (2019), Statistic Finland (2019c) and Finnish Forest Industries database. Emissions evaluated using emission intensities in Table 4

Funding Open access funding provided by LUT University (previously Lappeenranta University of Technology (LUT)). This study was funded by the Academy of Finland (grant number 315019).

Open Access This article is licensed under a Creative Commons Attribution 4.0 International License, which permits use, sharing, adaptation, distribution and reproduction in any medium or format, as long as you give appropriate credit to the original author(s) and the source, provide a link to the Creative Commons licence, and indicate if changes were made. The images or other third party material in this article are included in the article's Creative Commons licence, unless indicated otherwise in a credit line to the material. If material is not included in the article's Creative Commons licence and your intended use is not permitted by statutory regulation or exceeds the permitted use, you will need to obtain permission directly from the copyright holder. To view a copy of this licence, visit http://creativecommons.org/licenses/by/4.0/.

\section{References}

Alakangas E, Hurskainen M, Laatikainen-Luntama J, Korhonen J (2016) Properties of indigenous fuels in Finland. https://cris.vtt.fi/en/publications/properties-of-indigenous-fuels-in-finland. Accessed 1 February 2020

Bolkesjo TF, Obersteiner M, Solberg B (2003) Information technology and the newsprint demand in Western

Europe: a Bayesian approach. Can J of Forest Res 33:1644-1652. https://doi.org/10.1139/x03-083

Boreal Bioref. Operations. http://www.borealbioref.fi/en/operations/. Accessed 17 December 2019 
Buongiorno J (1996) Forest sector modeling: a synthesis of econometrics, mathematical programming, and system dynamics methods. Int J Forecasting 3:329-343. https://doi.org/10.1016/0169-2070(96)00668-1

Buongiorno J, Zhang D, Rytkonen A, Zhang Y, Zhu S, Tomberlin D (1998) Long-term forecasting of international forest product markets: the GFPM model and implications for Europe. IDEAS Working Paper Series from RePEc

Energy Authority. Mills' emissions 2013-2018 (in Finnish) https://energiavirasto.fi/en/publications- of-theemissions-trading. Accessed 10 November 2019

Ericsson K, Nilsson LJ, Nilsson M (2011) New energy strategies in the Swedish pulp and paper industry — the role of national and EU climate and energy policies. Energ Policy 39:1439-1449. https://doi.org/10.1016/j.enpol.2010.12.016

European Commission (2019) Communication from the commission to the European parliament, the European council, the council, the European economic and social committee and the committee of the regions. European Green Deal

European Commission (n.d.) 2030 Climate \& energy framework. https://ec.europa.eu/clima/policies/strategies/ 2030 en. Accessed 29 October 2019

Finnish Energy. Energy year 2019 (2020) https://energia.fi/files/4355/Energiavuosi_2019_Sahko.pdf. Accessed 4 February 2020

Finnish Forest Industries (2010) A forerunner in the bioeconomy. https:/www.metsateollisuus.fi/uploads/2017/ 03/30041812/893.pdf. Accessed 8 September 2020

Finnish Forest Industries (2018) Energy and Logistic. https://www.forestindustries.fi/statistics/energyandlogistics/. Accessed 18 December 2019

Finnish Government (2019) The act banning the use of coal for energy generation in 2029 to enter into force in early https:/valtioneuvosto.fi/en/article/-/asset_publisher/1410877/kivihiilen-energiakayton-vuonna-2029kieltava-laki-voimaan-huhtikuun-alussa. Accessed 27 November 2019

Fleiter T, Fehrenbach D, Worrell E, Eichhammer W (2012) Energy efficiency in the German pulp and paper industry - a model-based assessment of saving potentials. Energy 40:84-99. https://doi.org/10.1016/j. energy.2012.02.025

Food and Agriculture Organization of the United Nations (FAO) (2019) Forestry production and trade. http:// www.fao.org/faostat/en/\#data/FO. Accessed 25 September 2019

Fracaro G, Vakkilainen E, Hamaguchi M, Melegari, de Souza SN (2012) Energy efficiency in the Brazilian pulp and paper industry. Energies 5: 3550-3572. https://doi.org/10.3390/en5093550

Hamaguchi M, Cardoso M, Vakkilainen E (2012) Alternative technologies for biofuels production in Kraft pulp mills_potential and prospects. Energies 5:2288-2309. https://doi.org/10.3390/en5072288

Hämäläinen S, Näyhä A, Pesonen HL (2011) Forest biorefineries - a business opportunity for the Finnish forest cluster. J Clean Prod 19:1884-1891. https://doi.org/10.1016/j.jclepro.2011.01.011

Hänninen R, Katila P, Västilä S (2013) Change analysis of business environment of forest sector (in Finnish) http://www.metla.fi/ohjelma/mtu/pdf/Metla_toimintaymparistoanalyysi_22_5_2013.pdf. Accessed 10 November 2019

Hurmekoski E, Hetemäki L (2013) Studying the future of the forest sector: review and implications for long-term outlook studies. Forest Policy and Econ 34:17-29. https://doi.org/10.1016/j.forpol.2013.05.005

Hurmekoski E, Johnsson R, Korhonen J, Jänis J, Mäkinen M, Leskinen P, Hetemäki L (2018) Diversification of the forest industries: role of new wood-based products. Can J Forest Res 48:1417-1432. https://doi.org/10. 1139 /cjfr-2018-0116

Johnsson S, Andersson E, Thollander P, Karlsson M (2019) Energy savings and greenhouse gas mitigation potential in the Swedish wood industry. Energy 187:115919. https://doi.org/10.1016/j.energy.2019.115919

Johnston C (2016) Global paper market forecasts to 2030 under future internet demand scenarios. J Forest Econ 25:14-28. https://doi.org/10.1016/j.jfe.2016.07.003

Kähkönen S, Vakkilainen E, Laukkanen T (2019) Impact of structural changes on energy efficiency of Finnish pulp and paper industry. Energies 12:3689. https://doi.org/10.3390/en12193689

Kaicell Fibers (2020) The project in brief. http://www.kaicellfibers.net/project/. Accessed 10 February 2020

Kivistö A, Ikonen U, Tanskanen T, Vakkilainen E, Ojanen P, Pesari J (2013) Forest industry environmental strategy (governance); the forest industry development scenarios for 2020 (in Finnish). Centre for Economic Development, Transport and the Environment: Kouvola, Finland 70p

Koljonen T, Soimakallio S, Lehtilä A, Similä L, Honkatukia J, Hildén M, Rehunen A, Saikku L, Salo M, Savolahti M, Tuominen P, Vainio T (2019) Long-term development of total emissions (in Finnish) https:// tietokayttoon.fi/julkaisut/raportti?pubid=URN:ISBN:978-952-287-656-0. Accessed 20 December 2019

Kong L, Hasanbeigi A, Price L (2016) Assessment of emerging energy-efficiency technologies for the pulp and paper industry: a technical review. J Clean Prod 122:5-28. https://doi.org/10.1016/j.jclepro.2015.12.116 
Kuparinen K, Vakkilainen E, Tynjälä T (2019) Biomass-based carbon capture and utilization in Kraft pulp mills. Mitigation Adapt Strat Global Change 24:1213-1230. https://doi.org/10.1007/s11027-018-9833-9

Lundmark T, Bergh J, Hofer P, Lundström A, Nordin A, Poudel B, Sathre R, Taverna R, Werner F (2014) Potential roles of Swedish forestry in the context of climate change mitigation. Forests 5:557-578. https:// doi.org/10.3390/f504557

Metsä Fibre (n.d.-a) Äänekoski bioproduct mill. https://www.metsafibre.com/en/about-us/Production-units/ Bioproduct-mill/Pages/default.aspx. Accessed 18 December 2019

Metsä Fibre (n.d.-b) Kemi biorefinery project (in Finnish) https://www.metsafibre.com/fi/yhtio/Keminbiotuotetehdas/Pages/default.aspx. Accessed 17 Dec 2019

Ministry of Economic Affairs and Employment (2017) Government report on the National Energy and climate strategy for 2030 (in Finnish). Helsinki, Finland, 121 p

Ministry of the Environment (2020) Government's climate policy: carbon-neutral Finland by 2035. https:// wwwymfi/enUS/The_environment/Climate_and_air/CarbonNeutral_Finland_2035 Accessed 4 April 2020

Möllerstein K, Gao L, Jinyue Y (2006) $\mathrm{CO}_{2}$ capture in pulp and paper mills: $\mathrm{CO}_{2}$ balances and preliminary cost assessment. Mitigation Adapt Strat Global Change 11:1129-1150. https://doi.org/10.1007/s11027-0069026-9

Natural Resources Institute Finland (Luke) (2018) 12th National forest inventory: wood resources continue to grow. (in Finnish) https://www.luke.fi/uutinen/valtakunnan-metsien-12-inventointi-vmi12-puuvaratkasvavat-edelleen/.

Natural Resources Institute Finland (Luke) (2019) The consumption of domestic roundwood reached a new record in 2018. https://www.luke.fi/en/news/the-consumption-of-domestic-roundwood-reached-a-newrecord-in-2018/. Accessed 18 December 2019

Natural Resources Institute Finland (Luke). Luke's provincial estimates of forest production, use and carbon sinks have been published (in Finnish) (2020) https://www.luke.fi/uutinen/luken maakunnittaiset-arviot-metsientuotanto-ja-kayttomahdollisuuksista-seka-hiilinieluista-julkaistu/ Accessed 13 February 2020

Nyström I, Cornland D (2003) Strategic choices: Swedish climate intervention policies and the forest industry's role in reducing $\mathrm{CO}_{2}$ emissions. Energ Policy 31:937-950. https://doi.org/10.1016/S0301-4215(02)00137-4

Odyssee-Mure (2015) Energy efficiency trends and policies in industry. An analysis based on the ODYSSEE and MURE databases

Pöyry (2016) Finnish forest industry 2015-2035 (in Finnish). https://tem.fi/documents/1410877/2772829/P\% C3\%B6yry_Suomen+mets\%C3\%A4teollisuus+2015-2035.pdf/ac9395f8-8aea-4180-9642-c917e8c23ab2.

Siljander R, Ekholm T (2018) Integrated scenario modelling of energy, greenhouse gas emissions and forestry. Mitigation Adapt Strat Global Change 23:783-802. https://doi.org/10.1007/s11027-017-9759-7

Solnørdal M, Foss L (2018) Closing the energy efficiency gap - a systematic review of empirical articles on drivers to energy efficiency in manufacturing firms. Energies 11:518-549. https://doi.org/10.3390/ en1 1030518

St1 (2019) Cellunolix® biorefinery (in Finnish) https://smy.fi/wp-. Accessed 17 December 2019

Statistics Finland (2019a) PxWeb databases. http://pxnet2.stat.fi/PXWeb/pxweb/fi/StatFin/StatFin_ene_ehk/? tablelist=true. Accessed 20 January 2020

Statistics Finland (2019b) Greenhouse gas emissions in Finland in 2018. (in Finnish). https://www.stat.fi/til/khki/ 2018/khki_2018_2019-05-23_kat_001_fi.html. Accessed 4 February 2020

Statistics Finland. National accounts $(2019 \mathrm{c}) \mathrm{http}$ ://tilastokeskus.fi/tup/suoluk/suoluk_kansantalous_en.html. Accessed 25 September 2019

Stenqvist C (2015) Trends in energy performance of the Swedish pulp and paper industry: 1984-2011. Energy Efficiency 8:1-17. https://doi.org/10.1007/s12053-014-9276-4

Stora Enso (n.d.-a) Lineo By Stora Enso. Available online: https:/www.storaenso.com/en/products/lignin/lineo. Accessed 17 December 2019

Stora Enso (n.d.-b) Dissolving pulp for textiles and other applications. https:/www.storaenso.com/fi-fi/products/ market-pulp/dissolving-pulp-for-textiles-and-other-applications. Accessed 17 December 2019

Szabó L, Soria A, Forsström J, Keränen J, Hytönen E (2009) A world model of the pulp and paper industry: demand, energy consumption and emission scenarios to 2030. Environ Sci and Policy 12:257-269. https:// doi.org/10.1016/j.envsci.2009.01.011

Teir S, Arasto A, Tsupari E, Koljonen T, Kärki J, Kujanpää L, Lehtilä A, Nieminen M, Aatos S (2011) Hiilidioksidin talteenoton ja varastoinnin (CCS:n) soveltaminen Suomen olosuhteissa (In Finnish). Espoo VTT Tiedotteita - Research Notes 2576:76p

Trudeau N, Tam C, Graczyk D, Taylor P (2011) Energy transition for industry: India and the global context. Paris, France, IEA (International Energy Agency) 
UPM (2020) Vähemmän $\mathrm{CO}_{2}$ päästöjä (in Finnish). https://wwwupmcom/fi/vastuullisuus/ymparisto/vahemmanco2-paastoja/ Accessed 10 September 2020

UPM Biofuels (2020). UPM Lappeenranta Biorefinery. https://www.upmbiofuels.com/about-upm-biofuels/ production/upm-lappeenranta-biorefinery/. Accessed 17 January 2020

Wahlström J, Koskela J, Riikonen J, Hanlakin V (2017) Energy tax subsidies and cost efficient energy security (in Finnish). http://julkaisut.valtioneuvosto.fi/handle/10024/161852. Accessed 6 April 2020

Publisher's note Springer Nature remains neutral with regard to jurisdictional claims in published maps and institutional affiliations. 